\title{
Primary Cell Culture
}

National Cancer Institute

\section{Source}

National Cancer Institute. Primary Cell Culture. NCI Thesaurus. Code C19315.

The cells taken from a tissue source, and their progeny, grown in culture before subdivision and transfer to a sub culture. 